\title{
Fluoride Release Profile of a Nanofilled Resin-Modified Glass Ionomer Cement
}

\author{
Marco Aurélio Benini PASCHOAL ${ }^{1}$ \\ Carla Vecchione GURGEL ${ }^{1}$ \\ Daniela RIOS ${ }^{1}$ \\ Ana Carolina MAGALHÃES ${ }^{2}$ \\ Marília Afonso Rabelo BUZALAF² \\ Maria Aparecida de Andrade Moreira MACHADO ${ }^{1}$ \\ ${ }^{1}$ Department of Pediatric Dentistry, Orthodontics and Community Health, Bauru Dental School, \\ USP - University of São Paulo, Bauru, SP, Brazil \\ ${ }^{2}$ Department of Biological Sciences, Bauru Dental School, USP - University of São Paulo, Bauru, SP, Brazil
}

\begin{abstract}
The present study aimed to compare the fluoride $\left(\mathrm{F}^{-}\right)$release pattern of a nanofilled resin-modified glass ionomer cement (GIC) (Ketac N100 - KN) with available GICs used in dental practice (resin-modified GIC - Vitremer - V; conventional GIC - Ketac Molar - KM) and a nanofilled resin composite (Filtek Supreme - RC). Discs of each material $(n=6)$ were placed into 4 mL of deionized water in sealed polyethylene vials and shaken, for 15 days. $\mathrm{F}^{-}$release $\left(\mu \mathrm{g} \mathrm{F}^{-} / \mathrm{cm}^{2}\right)$ was measured each day using a fluoride-ion specific electrode. Cumulative $\mathrm{F}^{-}$release means were statistically analyzed by linear regression analysis. In order to analyze the differences among materials and the influence of time in the daily $\mathrm{F}^{-}$release, 2-way ANOVA test was performed $(\alpha=0.05)$. The linear fits between the cumulative $\mathrm{F}^{-}$release profiles of $\mathrm{RC}$ and $\mathrm{KM}$ and time were weak. $\mathrm{KN}$ and $\mathrm{V}$ presented a strong relationship between cumulative $\mathrm{F}^{-}$release and time. There were significant differences between the daily $\mathrm{F}^{-}$release overtime up to the third day only for GICs materials. The daily $\mathrm{F}^{-}$release means for $\mathrm{RC}$ were similar overtime. The results indicate that the $\mathrm{F}^{-}$release profile of the nanofilled resin-modified GIC is comparable to the resin-modified GIC.
\end{abstract}

Key Words: glass ionomer cement, fluoride, in vitro.

\section{INTRODUCTION}

The glass ionomer cements (GIC) are waterbased cements, known as polyalkenoate cements. Their generic name is based on the reaction between fluoroaluminosilicate glass and polyalkenoic acid, and setting results from an acid/base reaction between the components (1).

These cements have unique properties such as biocompatibility, adhesion to moist tooth structure, coefficient of thermal expansion similar to the tooth structure and anticariogenic action, due to $\mathrm{F}^{-}$release (2). The conventional glass ionomer systems, however, present certain limitations, which are the short working time, the long set time, susceptibility to early moisture contamination, desiccation after setting and brittleness
(3). Significant improvements have been made since the initial development of conventional GICs and further improvements are required in order to enhance their physical properties $(1,4)$.

As stated above, one of the advantages of GIC is its ability to inhibit recurrent caries (5), mainly due to its $\mathrm{F}^{-}$release property (6). However, there are a great variance in $\mathrm{F}^{-}$release among different types of GICs, probably due to the differences in composition, powder/liquid ratio and mixing time $(1,5)$. In addition, it has been noted that decreased physical properties are associated with increased $\mathrm{F}^{-}$-release, so research into the development of $\mathrm{F}^{-}$containing materials is ongoing with the hope of maintaining the physical properties of these materials and providing long $\mathrm{F}^{-}$release (7).

Nowadays, nanotechnology, also known as

Correspondence: Profa. Dra. Maria Aparecida de Andrade Moreira Machado, Departamento de Odontopediatria, Ortodontia e Saúde Coletiva, Faculdade de Odontologia de Bauru, USP, Alameda Octávio Pinheiro Brisolla, 9-75, 17012-901 Bauru, SP, Brasil. Tel: +55-14-3235-8224 Fax: +55-14-3223-4679. e-mail: mmachado@fob.usp.br 
molecular nanotechnology or molecular engineering, has been introduced in dental field providing a cosmetically acceptable restoration with excellent mechanical properties (8). The main point involved with this new trend is the addition of nanofillers particles to resin-based restorative materials. Recently, a nanofilled resin-modified GIC has become commercially available. This new material intends to bring adequate mechanical properties, to enhance aesthetic in terms of smoothness, polishability and precision of shade characterization (9). However, it is necessary to clarify the effect of the addition of nanoparticles along with fluoroaluminosilicate glass on its $\mathrm{F}^{-}$release profile.

Thus, the aim of the present study was to evaluate the F- release pattern of a nanofilled GIC (Ketac N100; 3M ESPE St. Paul, MN, USA) in deionized water, comparing it to a conventional GIC (Ketac Molar Easy Mix; 3M ESPE), a resin-modified GIC (Vitremer; 3M ESPE) and a nanofilled resin composite (Filtek Supreme; 3MESPE). The null hypothesis formulated was that there are no significant differences in the $\mathrm{F}^{-}$release pattern among the four materials studied over time, within the parameters investigated.

\section{MATERIAL AND METHODS}

The restorative materials used in the present study were a nanofilled resin composite (Filtek Supreme - RC), a conventional GIC (Ketac Molar Easymix - KM), a resin-modified GIC (Vitremer - V) and a nanofilled resin-modified GIC (Ketac N100 - KN). Details about the materials are given in Table $1(10)$.

\section{Sample Preparation Process}

Six disc specimens $(10 \mathrm{~mm}$ diameter x $1.5 \mathrm{~mm}$ height) of each material was dispensed into disposable cylindrical polytetrafluoroethylene moulds in the form of round discshaped samples. All restorative materials were prepared according to the manufacturers' instructions at room temperature $\left(23 \pm 1^{\circ} \mathrm{C}\right)$ and controlled relative humidity $(50 \pm 5 \%)$, according to ISO specification \#7489. After placement of the material in the mould, the surface of the restorative materials was covered with a polyester strip and a glass slab under pressure to expel excess material from the mould. For the light-cured materials, the polymerization procedure was carried out through the polyester strip following the manufacturers' recommended exposure time, using a light-curing device with a visible light intensity of $500 \mathrm{~mW} / \mathrm{cm}^{2}$ (Dabi Atlante, Ribeirão Preto, SP, Brazil). All samples were removed from the moulds after $10 \mathrm{~min}$.

\section{Determination of Fluoride Release}

Each specimen was placed in a polyethylene vial filled with $4 \mathrm{~mL}$ of deionized water, which was changed daily and kept under agitation at $1.4 \mathrm{~Hz}, 37^{\circ} \mathrm{C}$, for 15 days (2). A nylon thread was incorporated into the materials during setting, to place the specimens suspended in deionized water.

$\mathrm{F}^{-}$- release was determined in each day after buffering the solutions with equal volumes of TISAB II (Total Ionic Strength Adjustment Buffer, Analion). $\mathrm{F}^{-}$was measured with a $\mathrm{F}^{-}$ion specific electrode (Orion 96-09; Orion Research Inc., Cambridge, MA, USA) connected to an ion digital analyzer (Procyon SA 720; Orion Research Inc.). The electrode was previously calibrated with standards solutions of $0,0.1,0.2,0.4$, $0.8,1.6,3.2,6.4,12.8,25.6,51.2 \mu \mathrm{g} \mathrm{F} / \mathrm{mL}$. The $\mathrm{mV}$ readings were transformed into $\mu \mathrm{gF} / \mathrm{cm}^{2}$.

\section{Statistical Analysis}

In order to investigate $\mathrm{F}^{-}$release amounts and
Table 1. Restorative materials used in the study.

\begin{tabular}{|c|c|c|c|c|}
\hline Brand & Category & $\begin{array}{c}\text { Batch no. } \\
\text { (Powder/liquid) }\end{array}$ & $\begin{array}{c}\text { Powder } \\
\text { liquid ratio }\end{array}$ & $\begin{array}{l}\text { Mean filler } \\
\text { size }\end{array}$ \\
\hline \multirow{2}{*}{$\begin{array}{l}\text { Filtek } \\
\text { Supreme* }\end{array}$} & \multirow{2}{*}{$\begin{array}{c}\text { Resin } \\
\text { composite }\end{array}$} & \multirow{2}{*}{$5 \mathrm{AX}$} & \multirow{2}{*}{--} & $\begin{array}{l}\text { Nanocluster: } \\
0.6-1.4 \mu \mathrm{m}\end{array}$ \\
\hline & & & & $\begin{array}{l}\text { Nanofiller: } \\
20 \mathrm{~nm}^{* *}\end{array}$ \\
\hline $\begin{array}{l}\text { Ketac Molar } \\
\text { EasyMix }\end{array}$ & $\begin{array}{c}\text { Conventional } \\
\text { GIC }\end{array}$ & $\begin{array}{l}308161 \\
305465\end{array}$ & 2.9:1 & $14 \mu \mathrm{m}^{* *}$ \\
\hline Vitremer* & $\begin{array}{l}\text { Resin-modified } \\
\text { GIC }\end{array}$ & $\begin{array}{l}7 \mathrm{MX} \\
3303 \mathrm{~L}\end{array}$ & $2.5: 1$ & $3 \mu \mathrm{m}^{* * *}$ \\
\hline $\begin{array}{l}\text { Ketac } \\
\text { N100* }\end{array}$ & $\begin{array}{l}\text { Nanofilled resin- } \\
\text { modified GIC }\end{array}$ & K3K3 & $\begin{array}{l}\text { Paste/ } \\
\text { paste }\end{array}$ & $\begin{array}{l}\text { Data not } \\
\text { available }\end{array}$ \\
\hline
\end{tabular}

GIC $=$ Glass ionomer cement. *Manufacturer: 3M ESPE St. Paul, MN, USA.

${ }^{* *}$ Manufacturer information. ${ }^{* * *}$ Information from Xu and Burgess (10). 
patterns of the materials studied, it was used a linear regression model involving a qualitative factor by using the statistical software MINITAB 14. Two-way repeatedmeasures ANOVA were then performed to compare the interactions between the factors (types of materials for each time point). In order to assess significant differences within these factors, Tukey's test was applied. The value of $p<0.05$ was set as the level of statistical significance.

\section{RESULTS}

Figure 1 shows the cumulative $\mathrm{F}^{-}$release pattern for all restorative materials overtime. The linear fits between the cumulative $\mathrm{F}$ - release profiles of $\mathrm{RC}$ and $\mathrm{KM}$ and time were weak (RC: $\left.\mathrm{r}^{2}=0.21 / \mathrm{KM}: \mathrm{r}^{2}=0.40, \mathrm{p}>0.05\right)$. The low $\mathrm{r}^{2}$-value detected indicated a high scattering of the values for RC and KM. On the other hand, $\mathrm{KN}$ and $\mathrm{V}$ presented a strong relationship between cumulative $\mathrm{F}^{-}$release and time (KN: $\left.\mathrm{r}^{2}=0.95 / \mathrm{V}: \mathrm{r}^{2}=0.95, \mathrm{p}<0.05\right)$, which, in turn, means that these materials were able to keep a constant $\mathrm{F}^{-}$release pattern overtime.

Regarding the daily F- release, two-way repeatedmeasures ANOVA revealed significant differences among the restorative materials $(\mathrm{F}=13.64, \mathrm{p}<0.0001)$, time $(\mathrm{F}=52.85, \mathrm{p}<0.0001)$ and interaction between the variables $(\mathrm{F}=31.08, \mathrm{p}<0.0001)$. Generally, all GICs presented the highest $\mathrm{F}^{-}$amount released at the first day. Only for GIC materials (KM, KN and V), there were significant differences between the daily $\mathrm{F}^{-}$release overtime up to the third day, after which a plateau was shown. The daily $\mathrm{F}^{-}$release means for $\mathrm{RC}$ was low and similar overtime. When GICs were compared, $\mathrm{KN}$ and

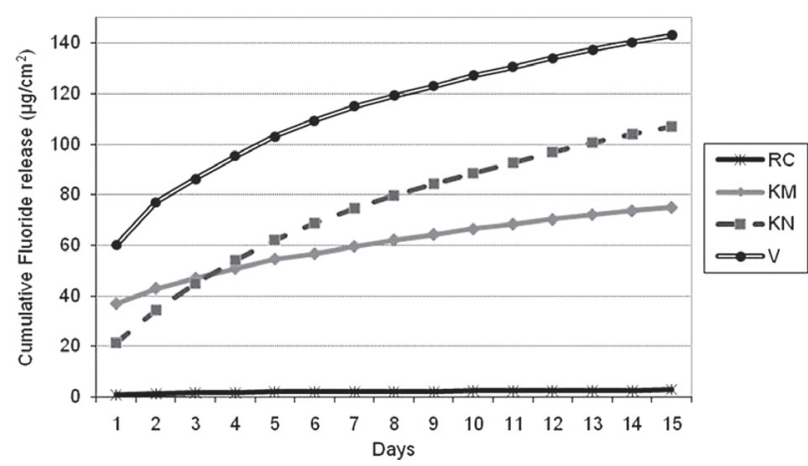

Figure 1. The regression line and the cumulative fluoride release points for the restorative materials at each day. Black circle $=\mathrm{V}$ $\left(r^{2}=0.95,[F]=22.85 \sqrt{ } t-1.70 t+9.86\right) ;$ dark grey square $=\mathrm{KN}$ $\left(\mathrm{r}^{2}=0.95,[\mathrm{~F}]=20.11 \sqrt{\mathrm{t}}-0.95 \mathrm{t}-8.57\right)$; bright grey diamond $=$ $\mathrm{KM}\left(\mathrm{r}^{2}=0.40,[\mathrm{~F}]=7.82 \sqrt{\mathrm{t}}-0.20 \mathrm{t}+11.16\right)$; black asterisk $=\mathrm{RC}$ $\left(r^{2}=0.21,[F]=0.57 \sqrt{ } t-0.05 t-0.04\right)$.
V significantly differ from KM up to the seventh and sixth day, respectively; KN was significant different from $\mathrm{V}$ up to second day (Fig. 2).

Based on the findings, the null hypothesis was partially accepted.

\section{DISCUSSION}

Several investigations have been performed on $\mathrm{F}^{-}$ release from dental materials, as this property is related to their cariostatic effect (6). The release of $\mathrm{F}^{-}$from dental materials is governed by various intrinsic and extrinsic factors. The intrinsic factors include composition, powder/liquid ratio, mixing time, temperature, specimen geometry, permeability, surface treatment and finishing (11). Temperature, specimen geometry, permeability, surface treatment and finishing were standardized for all materials. However, the composition, powder/ liquid ratio and mixing time vary in according to the studied materials. Extrinsic factors include type of storage medium, experimental design and analytical methods (12). These extrinsic factors make difficulty any comparison between our data and those from other studies.

Since the restorative materials do not have similar composition, the discussion of the results are mainly based on the comparison of the cumulative $\mathrm{F}^{-}$release pattern rather than the $\mathrm{F}^{-}$release differences among materials at each day. The daily $\mathrm{F}^{-}$release mean might be influenced by several factors, such as the storage medium, being of less importance to the scientific knowledge (13).

Deionized water is a medium that have been used for many years to evaluate the $\mathrm{F}^{-}$release from dental materials (14). Over the last years, some authors suggested that saliva or $\mathrm{pH}$-cycling models could better

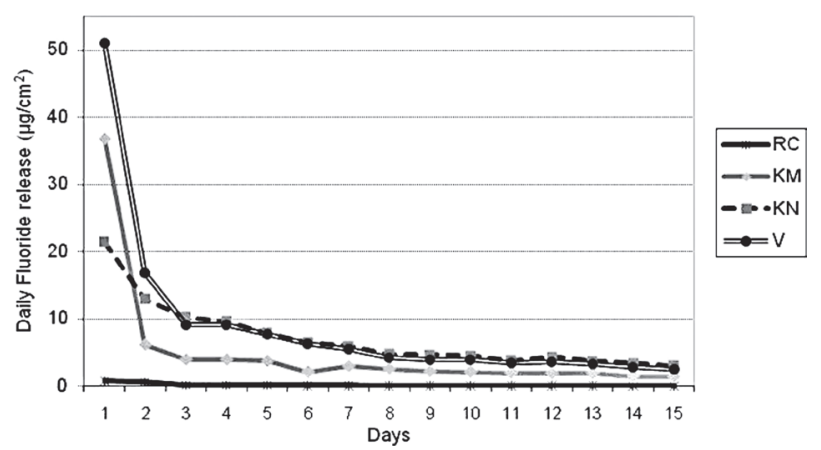

Figure 2. Daily fluoride release means (points) for the restorative materials. 
simulate the oral environment and, consequently, be more appropriated to study the $\mathrm{F}^{-}$release from the materials $(1,15)$. In spite of this fact, deionized water is a medium that reflects well the property of the material to release $\mathrm{F}^{-}$without any influence of minerals or organic molecules which might be presented into de/re solutions or saliva. Studies have shown that highest values of $\mathrm{F}^{-}$release from dental materials were observed in $\mathrm{pH}-$ cycling models, when compared with deionized water. In fact, the most important finding is not the amount of $\mathrm{F}^{-}$released from the material, but the $\mathrm{F}^{-}$release pattern overtime. Accordingly, Garcez et al. (13) found that the $\mathrm{F}^{-}$release pattern from restorative materials were similar in deionized water and in solutions simulating pH-cycling.

There are several studies showing higher (5), similar $(16,17)$ and lower $\mathrm{F}^{-}$release rates (3) for conventional GICs, when compared with resin-modified GICs. These discrepant findings are mainly related to the extrinsic factors present in each study. In accordance with our findings, Dionysopoulos et al. (3) showed that the conventional GIC (KM) released less $\mathrm{F}^{-}$compared with resin-modified GIC (V). The hypothesis given by the authors was that the low solubility and the high powder/ liquid ratio of the KM could explain this difference (3).

Differences in $\mathrm{F}^{-}$release profiles between various fluoride-containing materials have been reported $(5,6,18)$. A previous study has shown that $\mathrm{F}^{-}$release from glass ionomer cements occurs by means of three mechanisms: surface loss, diffusion through pores and cracks, and bulk diffusion (19). The highest $\mathrm{F}^{-}$release from the restorative materials studied was observed at the first day and decreased thereafter up to the third day. The high level of $\mathrm{F}^{-}$release on the first day might have been caused by the initial surface loss; while the relatively constant $\mathrm{F}^{-}$release during the following days might be due to the $\mathrm{F}^{-}$ability to diffuse through cement pores and fractures $(11,15)$. Bulk $\mathrm{F}^{-}$diffusion occurs during the maturation period as a consequence of the contact of the material with the storage medium. The $\mathrm{F}^{-}$release pattern found in the present study is in accordance with the literature $(3,5,7,15)$.

The present study showed that KN presented a similar cumulative $\mathrm{F}^{-}$release pattern to $\mathrm{V}$ (Fig. 1). The differences between both resin-modified GICs' compositions are mainly related to the presence of nanoparticles in the KN. Based on this, it might be speculated that the nanoparticles presented in the tested GIC (KN) do not have influence on the cumulative $\mathrm{F}^{-}$ release profile, considering the experimental conditions of the present study.

This finding is in agreement to the daily $\mathrm{F}^{-}$release means, as the values of $\mathrm{KN}$ were closer to $\mathrm{V}$ than $\mathrm{KM}$ especially up to seventh day (Fig. 2). On the other hand, $\mathrm{KN}$ presented lower $\mathrm{F}^{-}$release than the other GICs at the first day. This phenomenon could be explained by its low solubility, since it was shown by scanning electron microscopy that the surface morphology of the $\mathrm{KN}$ does not reveal voids, cracks and microporosities after immersion in saline, as it was observed for all other GICs tested (18). In addition, it was also found that $\mathrm{KN}$ did not present superficial alterations even after immersion in acidic solution $(\mathrm{pH}=2.5)$ (18). In the present study, after the second day, $\mathrm{KN}$ presented a similar daily $\mathrm{F}^{-}$ release pattern to $\mathrm{V}$.

It is important to point out that the extrapolation of the laboratory findings to the in vivo performance of the restorative materials should be done carefully, as the conditions between both situations are different (19). The present study should be considered as a preliminary investigation limited on several distinct parameters. Only controlled clinical trials as well as more complex experimental designs comprising large number of factors, which might influence the properties of dental materials in real clinical situations, could provide more valid conclusions.

In the clinical situation, for example, components of saliva, acquired pellicle, $\mathrm{pH}$, ion concentration and temperature might decrease the $\mathrm{F}^{-}$diffusion from the restorative materials in the oral cavity (20). The daily use of $\mathrm{F}^{-}$incorporated into dentifrices and solutions could also affect the amount of $\mathrm{F}^{-}$uptake and release from the materials. Moreover, when $\mathrm{pH}$ decreases during cariogenic and erosive challenges, it is suggested that the $\mathrm{F}^{-}$release from the materials increases (18).

The $\mathrm{F}^{-}$release from the restorative materials could affect the carious process through of reduction of demineralization and increase the remineralization during and after the cariogenic challenges $(3,14,15)$. Nevertheless, the amount of $\mathrm{F}^{-}$necessary for an effective anticariogenic effect is still unknown.

Based on the results, it may be concluded that the fluoride release profile of the nanofilled resin-modified GIC (KN) is comparable to that of the resin-modified GIC (V). However, other properties (mechanical and chemical) of this nanofilled GIC should be investigated in further studies, such as wear resistance and roughness, before this new restorative material can be considered 
as a good option in dental practice.

\section{RESUMO}

O presente estudo teve como objetivo comparar o padrão de liberação de fluoreto $\left(\mathrm{F}^{-}\right)$de um cimento de ionômero de vidro (CIV) nanoparticulado modificado por resina (Ketac N100 - KN) com CIVs disponíveis na prática clínica (CIV modificado por resina - Vitremer - V; CIV convencional - Ketac Molar - KM) e uma resina composta nanoparticulada (Filtek Supreme - RC). Discos de cada material $(\mathrm{n}=6)$ foram imersos em $4 \mathrm{~mL}$ de água deionizada em frascos de polietileno e agitados durante 15 dias. A liberação de $\mathrm{F}^{-}\left(\mu \mathrm{g} \mathrm{F}-/ \mathrm{cm}^{2}\right)$ foi medida a cada dia utilizando um eletrodo de $\mathrm{F}^{-}$específico. Os valores de liberação cumulativa de $\mathrm{F}^{-}$foram analisados estatisticamente por análise de regressão linear. Com o objetivo de analisar as diferenças entre os materiais e a influência do tempo na liberação diária de $\mathrm{F}^{-}$foi aplicado o teste ANOVA a dois critérios $(\alpha=0,05)$. A relação entre os padrões de liberação de cumulativo de $\mathrm{F}^{-}$da $\mathrm{RC}$ e $\mathrm{KM}$ e o tempo foram fracas. Os materiais $\mathrm{KN} \mathrm{e} \mathrm{V}$ apresentaram uma relação forte entre a liberação cumulativa de $\mathrm{F}^{-} \mathrm{e}$ o tempo. Diferenças significativas foram observadas entre a liberação diária de $\mathrm{F}^{-}$até o terceiro dia somente para os cimentos ionoméricos. Os resultados indicam que o padrão de liberação de $\mathrm{F}^{-}$do CIV modificado por resina nanoparticulado é semelhante ao CIV modificado por resina.

\section{ACKNOWLEDGEMENTS}

We wish to thank Ms. Larissa Grizzo for her skilful technical assistance.

\section{REFERENCES}

1. Karantakis P, Helvatjoglou-Antoniades M, Theodoridou-Pahini $\mathrm{S}$, Papadogiannis Y. Fluoride release from three glass ionomers, a compomer and a composite resin in water, artificial saliva and lactic acid. Oper Dent 2000;25:20-25.

2. Kent BE, Lewis BG, Wilson AD. Glass ionomer cement formulations: I. The preparation of novel fluoroaluminosilicate glasses high in fluorine. J Dent Res 1979;58:1607-1619.

3. Dionysopoulos P, Kotsanos N, Pataridou A. Fluoride release and uptake by four new fluoride releasing restorative materials. J Oral Rehabil 2003;30:866-872.

4. Raggio DP, Bonifacio CC, Bonecker M, Imparato JCP, Gee AJ, Amerongen WEV. Effect of insertion method on knoop hardness of high viscous glass ionomer cements. Braz Dent J 2010;21:439445 .
5. Vermeersch G, Leloup G, Vrenen J. Fluoride release from glass ionomer cements, compomers and resin composites. J Oral Rehabil 2001;28:26-32.

6. Wiegand A, Buchalla W, Attin T. Review on fluoride-releasing restorative materials - fluoride release and uptake characteristics, antibacterial activity and influence on caries formation. Dent Mater 2007;23:343-362.

7. Khouw-Liu VHW, Anstice GI, Pearson GL. An in vitro investigation of a poly (vinyl phosphonic acid) based cement with four conventional glass-ionomer cements. Part 1: flexural strength and fluoride release. J Dent 1999;27:359-365.

8. Mitra SB, Wu D, Holmes BN. An application of nanotechnology in advanced dental materials. J Am Dent Assoc 2003;134:1382-1390.

9. Ketac N100. 3M ESPE AG Manufacturer. Seefeld [Bulla]. Germany: 3M; 2007 [cited 2007 nov 08]. Available from: http://solutions.3m.co.za/wps/portal/3m/en_ZA/3MESPE/ dentalprofessionals/products/category/direct-restorative/ketacnano/.

10. Xu X, Burgess JO. Compressive strength, fluoride release and recharge of fluoride-releasing materials. Biomaterials 2003;24:2451-2461.

11. Hattab FN, Amin WM. Fluoride release from glass ionomer restorative materials and the effects of surface coating. Biomaterials 2001;22:1449-1458.

12. Hörsted-Bindslev P. Fluoride release from alternative restorative materials. J Dent 1994;22 Supp11:S17-S20.

13. Garcez RMVB, Buzalaf MAR, Araújo PA. Fluoride release of six restorative materials in water and $\mathrm{pH}$-cycling solutions. J Appl Oral Sci 2007; 15:406-411.

14. Attar N, Önen A. Fluoride release and uptake characteristics of aesthetic restorative materials. J Oral Rehabil 2002;29:791-798.

15. Geurtsen W, Leyhausen G, Garcia-Godoy F. Effect of storage media on the fluoride release and surface microhardness of four polyacid-modified composite resins ("compomers"). Dent Mater 1999; 15:196-201.

16. Momoi Y, Mccabe JF. Fluoride release from light-activated glassionomer restorative cements. Dent Mater 1993;9:151-154.

17. Robertello FJ, Coffey JP, Lynde TA, King P. Fluoride release of glass ionomer-based luting cements in vitro. J Prosthet Dent 1999;82:172-176.

18. Markovic DL, Petrovic BB, Peric TO. Fluoride content and recharge ability of five glass ionomer dental materials. BMC Oral Health 2008;8:21-28.

19. Papagiannoulis L, Kakaboura A, Eliades G. In vivo vs in vitro anticariogenic behavior of glass-ionomer and resin composite restorative materials. Dent Mater 2002;18:561-569.

20. Bell A, Creanor SL, Foye RH, Saunders WP. The effect of saliva on fluoride release by a glass-ionomer filling material. J Oral Rehabil 1999;26:407-412. 